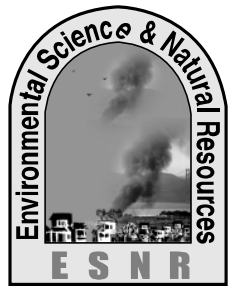

J. Environ. Sci. \& Natural Resources, 5(2): 199 - 203 , 2012

ISSN 1999-7361

\title{
Isolation of Phomopsis Inhibitory Fraction of Allamanda Extract Removing Gum and Other Undesirable Compounds
}

\author{
F. Ahmed ${ }^{1}$, M. B. Meah ${ }^{1}$ and F. Yasmin ${ }^{2}$ \\ ${ }^{1}$ Department of Plant Pathology, Bangladesh Agricultural University, Mymensingh-2202, Bangladesh \\ ${ }^{2}$ Soil Science Division, Bangladesh Agricultural Research Institute, Joydevpur, Gazipur, Bangladesh
}

\begin{abstract}
Allamanda leaf extracts were made by three organic solvents hexane, methanol and ethyl acetate having different polarities. Thin layer chromatography (TLC) of the refluxing extracts showed each of them contained considerable number of different compounds. By observing $R_{\mathrm{f}}$ value of these extracts it was confirmed that the compounds present in different extracts are not same and two of them (methanol and ethyl acetate) extracts were distilled to remove solvent for bioactivity test. In growth inhibition test, methanol and ethyl acetate extracts of allamanda inhibited mycelial growth of Phomopsis vexans. Ethyl acetate extract at $0.2 \%$ and $0.3 \%$ concentration inhibited $100 \%$ mycelial growth of Phomopsis vexans while methanol extract was not effective in suppressing growth rather it arrested temporarily the growth of Phomopsis vexans. Eggplant seeds treated with ethyl acetate extract in blotter produced higher percentage of seed germination $(85.00 \%)$ and healthy seedlings $(88.36 \%)$ and lower percentage of dead seed $(15.00 \%)$, and rotten seed $(5.89 \%)$ than those treated with methanol extract. In most cases, seed quality was improved with the increasing of concentration of ethyl acetate extract. It may be summarized that higher amount of antifungal compounds were present in ethyl acetate extract in purified form where methanol also have some compounds that inhibited partially growth of Phomopsis vexans.
\end{abstract}

Key words: Allamanda extract, Phomopsis vexans, Thin layer chromatography

\section{Introduction}

Allamanda (Allamanda cathertica) is a garden flowering plant belongs to the Apocynaceae family. It has a great medicinal value against plant disease. It contains anti-fungal activity, leaf extract has anti pathogenic action against fungus and bacteria (Kirtiker et al. 1975). Both Rasheduzzaman (2005) and Shabiha (2005) reported that extracts of leaf, flower and stem bark of Allamanda and solution of allamanda pellet gave more or less identical response in reducing the galls, egg masses and nematode populations in carrot and peas. It is an environment loving pesticide. As it is produced from plant parts so it has no harmful affect on the crop, mammals and human being.

Allamanda leaf extract consists of many chemical compounds from which antifungal components (Plumieride) has also been separated. But it has been observed that the allamanda tablet, a durable product made out of extract by IPM Lab BAU is hard in nature which is not easily soluble in water due to presence of gum and many undesirable compounds. For this reason purification of allamanda leaf extract is required to increase solubility and effectiveness of the allamanda pellet. An effective formulation for farmer level application is to be done. Therefore, the present research was undertaken to remove gum, oil and other undesirable compounds except Phomopsis inhibitory compounds from allamanda leaf extract.

\section{Materials and Method}

An experiment was conducted at the Plant Disease Diagnostic Clinic (PDDC), Department of Plant Pathology and Chemistry Laboratory, Department of Agricultural Chemistry, Bangladesh Agricultural University (BAU), Mymensingh, during March 2011 to April 2012.

\section{Allamanda extract preparation}

For preparation of allamanda extract, $100 \mathrm{~g}$ dried and powdered allamanda leaves were taken in a thimble and $750 \mathrm{ml} \mathrm{n}$-hexane was taken in a round bottom flask. The extraction was done by refluxing organic solvent (n-hexane) for about 10 hours in a water bath keeping the temperature not more than $65^{\circ} \mathrm{C} \pm 2^{0} \mathrm{C}$. At the end, allamanda extract was collected from refluxing apparatus and filtered). Then again the dried and extracted powder was taken in the thimble and $150 \mathrm{ml}$ n-hexane added in soxhlet apparatus. Extraction was continued for 15 hours in a water bath keeping the temperature not more than $65 \pm 2^{\circ} \mathrm{C}$. At the end allamanda extract was collected from soxhlet apparatus and the thimble was washed. The leaf extract was labeled and preserved in a conical flask for further use.

Same procedure was followed for the preparation of allamanda leaf extract by ethyl acetate and methanol by the same procedure. These three extracts were partially concentrated and used for bio-assay against Phomopsis vexans.

\section{Bio-assay of allamanda extracts}

Isolate-22 of Phomopsis vexans collected from IPM Lab, Department of Plant Pathology, BAU (Meah, 
2002) was used for bio-assay. Laboratory experiment for bio-assay of methanol and ethyl acetate extracts against Phomopsis vexans was set following Completely Randomized Design (CRD) with four treatments with four replications for each extracts and both extracts were tested separately against Phomopsis vexans in vitro following growth inhibition technique (Meah et al., 2002). Inhibition percentage of the Phomopsis vexans was calculated by the following formula as suggested by Sundar et al. (1995).

$$
\% \text { inhibition }=\frac{X-Y}{X} \times 100
$$

Where,

$\mathrm{X}=$ Mycelial growth/diameter of the colonies of Phomopsis vexans in absence of allamanda extracts i.e. control.

$\mathrm{Y}=$ Diameter of the colonies of Phomopsis vexans in presence of allamanda extracts i.e. methanol and ethyl acetate extracts.

\section{Seed treatment with allamanda extracts}

Eggplant seeds were left soaked in Phomopsis vexans suspension for 30 minutes. Then liquid was drained off and incubated in laminar air flow chamber for overnight. The sample seeds were dipped in the methanol and ethyl acetate extracts solution for $15 \mathrm{~min}$. The liquid was drained off seeds, shade dried before plating. The experiment was set following Completely Randomized Design (CRD) with five treatments and four replications for each extract. The treatments were no treatment+ pathogen uninoculated (Control), no treatment+ pathogen inoculated $\left(\mathrm{T}_{1}\right)$ and $0.1\left(\mathrm{~T}_{2}\right), 0.25\left(\mathrm{~T}_{3}\right)$ and $0.3 \%\left(\mathrm{~T}_{4}\right)$ of both extracts were used. Treated seeds were incubated in blotter following blotter technique (ISTA, 2004)

\section{Results and Discussion}

\section{Effect of methanol extracts against Phomopsis vexans}

In case of 24, 48, 72, 96 and 120 hours, there were significant differences between methanol extract and control treatment (untreated). Lowest mycelial growth and the highest percent of inhibition were obtained in $0.3 \%$ concentration. However, the growth inhibition decreased continuously with incubation time. This means the methanol extract was not effective in suppressing growth rather it arrested temporarily the growth of Phomopsis vexans (Fig. 1). This result agreed with the previous reports of Islam (2004) and Tania (2007) who reported that allamanda is one of the recognized plants, the extract of which has been proved effective in controlling Phomopsis vexans including other fungi.

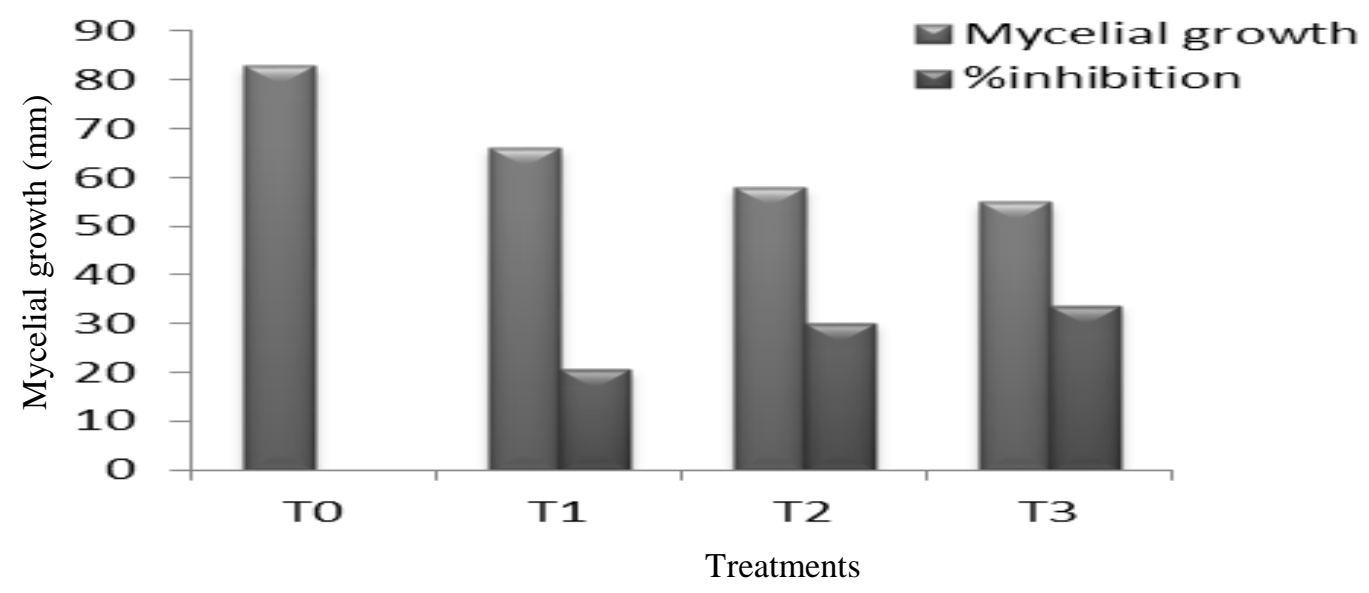

Fig. 1. Effects of methanol extract against Phomopsis vexans 


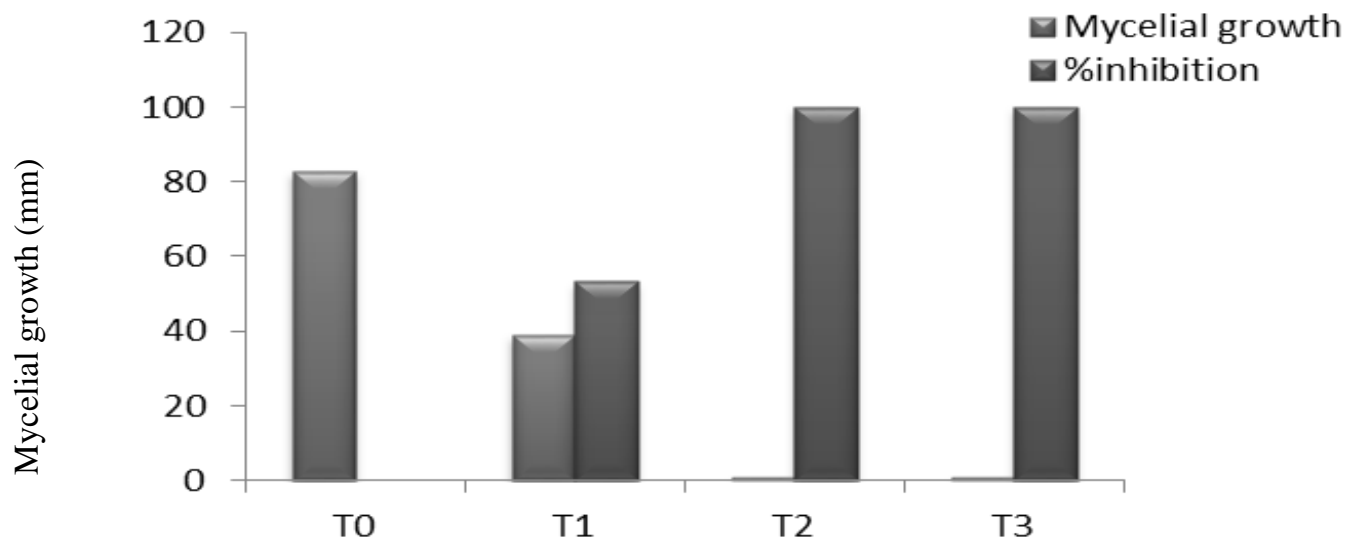

Treatments

Fig. 2. Effects of ethyl acetate extract against Phomopsis vexans

\section{Effects of ethyl acetate extract against Phomopsis vexans}

In case of 24, 48, 72, 96 and 120 hours, there were significant differences between ethyl acetate extract and control treatment (untreated). Among the treatments highest performance was displayed by 0.2 and $0.3 \%$ treatments (Fig. 2) where $100 \%$ inhibition was obtained. Percent inhibition of mycelial growth increased with increasing the concentration of ethyl acetate extract while no mycelial growth was found in both 0.2 and $0.3 \%$ treatments and statistically both were similar. Highest mycelial growth was found in control treatment while $0.1 \%$ conc. arrested temporarily the growth of Phomopsis vexans. However, the growth inhibition decreased continuously with incubation time. This means the ethyl acetate extract was very much effective in suppressing growth since no growth of Phomopsis vexans obtained at $0.2 \%$ and $0.3 \%$ concentration.

\section{Effects of treatment of eggplant seeds with} (Phomopsis inoculated) methanol extract

Highest percentage seed germination $(83.00 \%)$ was recorded in $0.3 \%$ treatment. The germination increased with increase in concentration of methanol extract. Lowest seed germination $(43.00 \%)$ was obtained in the untreated and inoculated seeds which were significantly lower than that in allamanda extract-in methanol treated seeds (Table 1). Abnormal seed germination was recorded the lowest $(4.65 \%)$ in untreated and pathogen inoculated seeds which was significantly lower than that in methanol extract treated seeds. Highest and lowest percentage dead seeds $(57.00 \%)$ and $(17.00 \%)$ were obtained in untreated and pathogen inoculated seeds and $0.3 \%$ conc. treatment respectively. Highest percentage of seedling blight was obtained $(23.25 \%$ ) in $0.1 \%$ treatment (untreated and pathogen inoculated seed). Lowest percentage of seedling blight was obtained $(8.00 \%)$ in the $0.2 \%$ conc. treatment. Seedling blight was significantly higher in $0.1 \%$ treatment than that in other allamanda extract treatments. The effect of 0.2 and $0.3 \%$ treatments were statistically similar. Highest percentage $(13.96 \%)$ rotten seed was obtained in the $0.1 \%$ treatment which was statistically similar with 00 and $0.2 \%$ treatment. Rotten seed were recorded $(8.44 \%)$ in the $0.3 \%$ treatment was the highest performance of seed treatment with allamanda extracts.

Highest percentage $(78.28 \%)$ healthy seedling was obtained in the $0.3 \%$ treatment. Healthy seedling was recorded $(73.34 \%)$ and $(73.42 \%)$ in 0.2 and $0.3 \%$ respectively which were statistically similar. Healthy seedling was recorded (48.14\%) in the $0.1 \%$ treatment which was untreated and pathogen inoculated seeds. 
Table 1. Effects of treatment of eggplant seeds with (Phomopsis inoculated) methanol extract of different concentration on seed germination and other seed qualities (Blotter method)

\begin{tabular}{|l|c|c|c|c|c|c|}
\hline $\begin{array}{l}\text { Treatment or } \\
\text { Concentration(\%) }\end{array}$ & $\begin{array}{c}\text { Seed } \\
\text { germination } \\
(\boldsymbol{\%})\end{array}$ & $\begin{array}{c}\text { Abnormal seed } \\
\text { germination } \\
(\boldsymbol{\%})\end{array}$ & $\begin{array}{c}\text { Dead seed } \\
(\boldsymbol{\%})\end{array}$ & $\begin{array}{c}\text { Seedling } \\
\text { blight } \\
(\%)\end{array}$ & $\begin{array}{c}\text { Rotten } \\
\text { seed } \\
(\%)\end{array}$ & $\begin{array}{c}\text { Healthy } \\
\text { seedling }(\boldsymbol{\%})\end{array}$ \\
\hline $\mathrm{T}_{0}$ (Control) & $56.00 \mathrm{c}$ & $26.79 \mathrm{a}$ & $44.00 \mathrm{a}$ & $8.925 \mathrm{c}$ & $7.15 \mathrm{a}$ & $47.17 \mathrm{c}$ \\
\hline $\begin{array}{l}\mathrm{T}_{1} \text { (no treatment+ } \\
\text { pathogen inoculated) }\end{array}$ & $43.00 \mathrm{~b}$ & $4.650 \mathrm{c}$ & $57.00 \mathrm{a}$ & $23.25 \mathrm{a}$ & $13.96 \mathrm{a}$ & $48.14 \mathrm{c}$ \\
\hline $\mathrm{T}_{2}(0.1)$ & $75.00 \mathrm{~b}$ & $5.340 \quad \mathrm{c}$ & $25.00 \mathrm{~b}$ & $8.00 \mathrm{c}$ & $13.34 \mathrm{a}$ & $73.34 \mathrm{~b}$ \\
\hline $\mathrm{T}_{3}(0.25)$ & $79.00 \mathrm{ab}$ & $6.330 \mathrm{~b}$ & $21.00 \mathrm{c}$ & $10.13 \mathrm{~b}$ & $10.13 \mathrm{~b}$ & $73.42 \mathrm{~b}$ \\
\hline $\mathrm{T}_{4}(0.3)$ & $83.00 \mathrm{a}$ & $8.440 \mathrm{a}$ & $17.00 \mathrm{~d}$ & $10.85 \mathrm{~b}$ & $8.440 \mathrm{c}$ & $78.28 \mathrm{a}$ \\
\hline Level of sig. & $* *$ & $* *$ & $* *$ & $* *$ & $* *$ & $* *$ \\
\hline CV\% & 4.12 & 8.60 & 3.57 & 7.05 & 7.28 & 2.88 \\
\hline
\end{tabular}

*100 seeds were evaluated for each treatment. Figures in a column with common letters do not differ at the P-values indicated.

\section{Effects of treatment of eggplant seeds (Phomopsis inoculated) with ethyl acetate extract}

Highest percentage seed germination $(85.00 \%)$ was recorded in 0.25 and $0.3 \%$ treatment. The germination increased with increase of concentration of ethyl acetate extract. Lowest seed germination $(43.00 \%)$ was obtained in the pathogen inoculated seeds which were significantly lower than that in allamanda extract treated seeds (Table 2). Abnormal seed germination was recorded the lowest $(3.52 \%)$ in $0.3 \%$ conc. treatment which was statistically similar with $\mathrm{T}_{1}$.

Highest percentage dead seed (57.00\%) was obtained in untreated and pathogen inoculated seeds. A lowest percentage dead seed $(15.00 \%)$ was obtained in the 0.25 and $0.3 \%$ which was statistically similar with $0.1 \%$. Highest percentage of seedling blight was obtained $(23.25 \%)$ in $\mathrm{T}_{1}$ treatment. Lowest percentage of seedling blight was obtained $(7.06 \%)$ in the $\mathrm{T}_{3}$ treatment which was statistically similar with $0.3 \%$ treatment. Highest percentage (13.96\%) rotten seed was obtained in the $\mathrm{T}_{1}$ treatment which was statistically similar with $\mathrm{T}_{0}$ and $0.1 \%$ treatment. Rotten seed and healthy seedlings was recorded $(5.89 \%)$ and $(88.36 \%)$ in the $0.3 \%$ treatment which was highest performance of seed treatment.

The findings are in agreement with the report of Hawlader (2003) who found that seed treatment with Allamanda leaf extracts effectively increased germination of eggplant seeds and tremendously decreased nursery diseases. This has also conformity with the findings of Panda et al. (1996) who reported leaf extract of Allamanda cathertica as an excellent potential fungicide for control of Phomopsis blight of brinjal. The findings also partially agree with the findings of Mahmud (2008) who reported that the garlic and allamanda tablet controlled the seedling diseases of eggplant.

Table 2. Effects of treatment of eggplant seeds with (Phomopsis inoculated) ethyl acetate extract of different concentration on seed germination and other seed qualities (Blotter method)

\begin{tabular}{|c|c|c|c|c|c|c|}
\hline $\begin{array}{l}\text { Treatment or } \\
\text { Concentration }(\%)\end{array}$ & $\begin{array}{c}\text { Seed } \\
\text { germination } \\
(\%)\end{array}$ & $\begin{array}{c}\text { Abnormal seed } \\
\text { germination }(\%)\end{array}$ & $\begin{array}{c}\text { Dead } \\
\operatorname{seed}(\%)\end{array}$ & $\begin{array}{c}\text { Seedling } \\
\text { blight } \\
(\%)\end{array}$ & $\begin{array}{c}\text { Rotten seed } \\
(\%)\end{array}$ & $\begin{array}{c}\text { Healthy } \\
\text { seedling } \\
(\%)\end{array}$ \\
\hline $\mathrm{T}_{0}($ Control $)$ & $56.00 \mathrm{c}$ & $26.79 \mathrm{a}$ & $44.00 \mathrm{a}$ & $8.925 \mathrm{c}$ & $7.15 \mathrm{c}$ & $47.17 \mathrm{c}$ \\
\hline $\begin{array}{l}\mathrm{T}_{1}(\text { no treatment }+ \\
\text { pathogen inoculated })\end{array}$ & $43.00 \quad b$ & $4.650 \mathrm{c}$ & $57.00 \mathrm{a}$ & $23.25 \mathrm{a}$ & $13.96 \mathrm{a}$ & $48.14 \mathrm{c}$ \\
\hline $\mathrm{T}_{2}(0.1)$ & $83.00 \mathrm{a}$ & $6.030 \mathrm{~b}$ & $17.00 \mathrm{~b}$ & $10.85 \mathrm{~b}$ & $7.230 \mathrm{c}$ & $75.81 \mathrm{~b}$ \\
\hline $\mathrm{T}_{3}(0.25)$ & $85.00 \mathrm{a}$ & $5.880 \mathrm{~b}$ & $15.00 \mathrm{~b}$ & $7.060 \mathrm{c}$ & $8.240 \mathrm{~b}$ & $78.82 \mathrm{~b}$ \\
\hline $\mathrm{T}_{4}(0.3)$ & $85.00 \mathrm{a}$ & $3.520 \mathrm{c}$ & $15.00 \mathrm{~b}$ & $8.240 \mathrm{c}$ & $5.890 \mathrm{~d}$ & $88.36 \mathrm{a}$ \\
\hline Level of sig. & $* *$ & $* *$ & $* *$ & $* *$ & $* *$ & $* *$ \\
\hline
\end{tabular}

*100 seeds were evaluated for each treatment. Figures in a column with common letters do not differ at the P-values indicated. 
Thin layer chromatography (TLC) of allamanda extracts at room temperature and using pure and different mixed solvents.

The TLC plates of allamanda extracts were developed by hexane, methanol, ethyl acetate, benzene and ethanol as carrier solvents and also following mixed solvents of suitable polarity were employed as carrier solvents.

Table 5. $\mathrm{R}_{\mathrm{f}}$ value of different spots by simple compounds present in different extracts of allamanda leaf powder

\begin{tabular}{|c|c|c|c|}
\hline Solvent of extraction & Carrier solvent (pure/mixed) & Ratio & $\mathbf{R}_{\mathbf{f}}$ value \\
\hline \multirow{2}{*}{ Hexane } & Hexane & Pure & $0.39,0.21,0.14,0.10$ \\
\cline { 2 - 4 } & Hexane: Benzene & $1: 1$ & $0.12,0.21$ \\
\hline \multirow{2}{*}{ Ethyl acetate } & Ethyl acetate & Pure & $1,0.86,0.29$ \\
\cline { 2 - 4 } & Ethyl acetate: Ethanol & $4: 1$ & $1,0.41$ \\
\cline { 2 - 4 } & Ethyl acetate: Benzene & $1: 1$ & $1,0.22,0.82,0.93$ \\
\hline \multirow{2}{*}{ Methanol } & Methanol & Pure & 0.85 \\
\cline { 2 - 4 } & Ethanol & Pure & $0.39,0.78,0.89$ \\
\cline { 2 - 4 } & Ethanol: Methanol & $1: 1$ & $0.21,0.43,0.96$ \\
\hline
\end{tabular}

\section{Conclusion}

Allamanda extract may be used as alternatives to chemical pesticide for controlling Phomopsis blight and seedling disease of eggplant especially caused by Phomopsis vexans which might be economic, easy to use and eco-friendly. As the active ingredient may remain in purified allamanda extract so the formulation might be more active than before which will be also sustainable for our farmers.

\section{References}

Hawlader, A. N. 2003. Effect of seed selection and seed treatment on the development of Phomopsis blight and fruit rot of eggplant. An M.S. thesis submitted to the Department of Plant Pathology, Bangladesh Agricultural University, Mymensingh. pp. 40-68.

International Seed Testing Association (ISTA). 2004. International Rules for Seed Testing. Seed Science and Technology. 335.

Islam, R. 2004. Chromatographic separation of components in garlic bulb and allamanda leaf extracts inhibitory to Phomopsis vexans. An M.S. thesis submitted to the Department of Plant Pathology, Bangladesh Agricultural University, Mymensingh. p. 35.

Kirtiker, K. R.; Basu, B. D. and An I. C. S. 1975. Indian medicinal plant, New Connaught place. Dehra Dun, 2(2): 1556-1557.

Mahmud, M. R. 2008. Determining durability of bioactivity of covered and uncovered garlic and allamanda tablet against seedling diseases of eggplant. An M.S. thesis submitted to the Department of Plant Pathology, Bangladesh Agricultural University, Mymensingh. pp. 1-20.
Meah, M. B.; Islam, M. R. and Hossain, D. M. 2002. Development of an integrated approach for management of Phomopsis blight and fruit rot of eggplant in Bangladesh. Annu. Res. Report, (2002-03) $51 \mathrm{p}$.

Meah, M. B. 2002. Development of an integrated approach for management of Phomopsis blight/fruit rot of eggplant in Bangladesh. BAU Res. Prog. 12: 33.

Panda, R. N.; Tripathy, S. K.; Kar, J. and Mohanty, A. K. 1996. Antifungal efficacy of Homeopathic drugs and leaf extracts in brinjal. Environment and Ecology, 14(2):292-294.

Rasheduzzman, M. 2005. Effect of soil amendment, plant extract and furadan $3 \mathrm{G}$ on the rootknot (Meloidogyne javanica) of carrot. An M.S. thesis submitted to the Department of Plant Pathology, Bangladesh Agricultural University, Mymensingh. pp. 1-16.

Shabiha, S. 2005. Effect of soil amendment, plant extracts and furadan $3 \mathrm{G}$ on the root-knot (Meloidogyne javanica) of pea. An M.S. thesis submitted to the Department of Plant Pathology, Bangladesh Agricultural University, Mymensingh. pp. 1-60.

Sundar, A. R.; Das, N. D. and Krishnaveni, D. 1995. In vitro antagonism of Trichoderma sp. against two fungal pathogens of castor. Ind. J. Plant Protec., 23: 152-155.

Tania, F. I. 2007. Investigation of structural characteristics of allamanda leaf extract components inhibiting the growth of some important plant pathogens. An MS thesis submitted to the Department of Plant Pathology, Bangladesh Agricultural University, Mymensingh. pp. 1-80. 